\title{
BOSNIA-HERZEGOVINA: THE ROLE OF THE JUDICIARY IN A DIVIDED SOCIETY
}

\author{
Joseph Marko* \\ Faculty of Law, University of Graz, Austria \\ josef.marko@uni-graz.at
}

\begin{abstract}
This paper analyzes the role of the Constitutional Court of Bosnia and Herzegovina for the promotion of social justice under the conditions of a triple transformation from war to peace and from a communist regime based on the Titoist self-management ideology to a liberal-democratic political regime and economic market system in three parts. The first section describes the political, constitutional and economic context during and after the collapse of the former Socialist Federal Republic of Yugoslavia and the war in Bosnia-Herzegovina. The second section describes and analyzes the constitutional and institutional arrangements established under the General Framework Agreement for Peace, concluded in Dayton/Ohio and Paris, 1995. The third section deals with the role of the Constitutional Court and analyzes with reference to its case law the interpretative doctrines developed in its adjudication of the right to property concerning different concepts of property and the right to work in the context of the constitutionally guaranteed right to return of refugees and restitution of property.
\end{abstract}

Keywords: Anti-discrimination, Constitutional Principles, Interpretative Doctrines, Power Sharing, Transitional Justice.

Professor of Comparative Public Law and Political Sciences at the University of Graz, Austria. Fmr international judge of the Constitutional Court of Bosnia and Herzegovina (1997-2002) and politico-legal adviser of the Special Adviser to the UN Secretary General on Cyprus, Espen Eide, in the negotiations on the re-unification of Cyprus (2016-2018). 


\section{INTRODUCTION:THE HISTORIC AND POLITICAL CONTEXT}

With the process of dissolution of the former Socialist Federal Republic of Yugoslavia (SFRY), which had been established by the victorious Yugoslav Communist Party after the end of the Second World War, the Socialist Republic of Bosnia and Herzegovina, having been one of the six federal entities of SFRY, was in a particularly difficult sandwich position in 1991. According to Lenin's and Stalin's model for communist federations, ${ }^{1}$ the federal entities of SFRY had constitutionally been seen as constitutive entities with the 'ethnic' majority population on the respective territory conceived as the state-forming nation for the respective 'Yugoslav' republics, namely Slovenia, Croatia, Serbia, Macedonia and Montenegro. However, as an exception from the rule and due to the historic legacy of the Ottoman and the Habsburg empires and the ensuing demographic situation with no ethnic group in an absolute majority position, Bosnia and Herzegovina could never be considered to be the state of one state-forming nation with other groups in the position of national minorities. Hence, three major groups, Muslims, originally categorized as a religious, not 'national' group, ${ }^{2}$ Serbs, and Croats were seen as 'constitutive' for this Yugoslav republic. In order to counteract centrifugal forces following from the state and nation building processes not only in Bosnia and Herzegovina ( $\mathrm{BiH})$, but all over Europe in the $19^{\text {th }}$ and the $20^{\text {th }}$ centuries, the Yugoslav Communist Party, under its victorious slogan Bratstvo i Jedinstvo (Brotherhood and Unity), took over a de facto system of proportional representation and participation of these three groups in all of the republican institutions. ${ }^{3}$ This system had already been developed under the Habsburg political system as conflict prevention mechanism, but was not taken over in the period between the two world wars with the establishment of the Kingdom of Serbs-Croats-Slovenes immediately after the First World War and its

Bill Bowring, The Degradation of the International Legal Order? The Rehabilitation of Law and the Possibility of Politics (New York: Routledge and Cavendish, 2008), 13-20.

2 Most authors on the history of state and nation building in Yugoslavia follow the official communist doctrine and party history that muslims with a lower-case ' $m$ ' were a religious, but not ethnic, group and thus legally recognized as an (ethnically conceived) nation only through the Republican Constitution of 1974, henceforth Muslims with a capital 'M.'

3 Mirsad Abazović, Nacionalni aspekti kadrova u BiH 1945-1991 [National Aspects of the Formation of Cadres in Bosnia and Herzegovina 1945-1991] (Sarajevo: Bibliotheka Posebna Izdanja, br. 66, 2000). 
transformation into the Yugoslav kingdom in 1927, both characterized by Greater Serbian aspirations for hegemony. Finally, in the course of transformation from a communist one-party system to a multi-party system in 1990, this institutional mechanism became constitutionally entrenched and formed the basis for the first multi-party elections in November 1990. However, due to the strong ethnic polarization of society with the foundation of political parties along ethnonational lines, the results of these elections resembled more a census. ${ }^{4}$

Hence, with the final breakdown of Communist Yugoslavia in the course of 1991 and the wars in Slovenia and Croatia in summer and fall of 1991, ${ }^{5}$ the newly elected tripartite Muslim/Serb/Croat government faced a problematic impasse when trying to remain 'neutral' and therefore 'independent' from any of the war-faring parties: on the one hand, both Muslim and Croat party leaders were afraid of being left over in a Serb-dominated 'rump Yugoslavia' under the leadership of the no longer socialist, but nationalist-authoritarian regime having been established by Slobodan Milošević in the Republics of Serbia and Montenegro, whereas, on the other, the political leader of the Serb Democratic Party (SDS) in $\mathrm{BiH}$, Radovan Karadžić, threatened war in case of a declaration of independence by a majority vote of Muslim and Croat representatives in parliament. All efforts to reach a political compromise failed and a fully fledged war broke out in $\mathrm{BiH}$ in April $1992 .{ }^{6}$

What are the consequences of the following four years of war in $\mathrm{BiH}$, stopped only by NATO-intervention based on a UN-Security Council mandate and followed by the Dayton Peace Agreement of December 1995? Already during

4 See Joseph Marko, "Defective Democracy in a Failed State? Bridging Constitutional Design, Politics and Ethnic Division in Bosnia-Herzegovina," in Practising Self-Government: A Comparative Study of Autonomous Regions, eds. Yash Gai and Sophia Woodman (Cambridge: Cambridge University Press, 2013), 286.

5 I have analyzed the political processes leading to the collapse of the SFRY in detail in Joseph Marko, "Processes of ethnic mobilization in the former Yugoslav Republics reconsidered," Southeastern Europe 34, no.1 (2010).

6 See Joseph Marko, "Autonomy or Partition? The Ethno-National Effects of Territorial Delimitation in Bosnia and Herzegovina," in Local-Self-Government, Territorial Integrity and Protection of Minorities, ed. Swiss Institute of Comparative Law, Publications of the Swiss Institute of Comparative Law (Zurich: Schulthess, 1996); Sabrina P. Ramet, The Three Yugoslavias: State-Building and Legitimitation, 1919-1992 (Washington: Indiana University Press, 2006), in particular 381-469.

7 The following description has been elaborated in detail by Marko, "Defective Democracy", fn 4 and Joseph Marko, "Ethnopolitics and Constitutional Reform in Bosnia and Herzegovina," in Bosnia-Herzegovina since Dayton: Civic and Uncivic Values, eds. Ola Listhaug and Sabrina P. Ramet (Ravenna: Longo Editore, 2013). 
the war, three new political units came into being. First, under the political leadership of R. Karadžić and the SDS, a new state, called 'Republika Srpska' (RS; not to be confused with the Republic of Serbia) was finally created by secession from the already internationally recognised Republic of Bosnia and Herzegovina in April 1992. Through military attack going hand in hand with ethnic cleansing, the military forces of RS, composed of the former Serb military personnel of the Yugoslav army from $\mathrm{BiH}$, held around 70 per cent of the entire territory of $\mathrm{BiH}$ until 1995. The second political unit, called 'Herceg-Bosna', was established in July 1992 by the political leaders of the Croatian party HDZ in those parts of Herzegovina that were defended by so-called 'Croatian Defence Forces' and which formed, at the beginning of the war, a military alliance with the army of the Republic of $\mathrm{BiH}$ under the political leadership of its president, Alija Izetbegović, a Muslim. However, after a war within the war had broken out between the Muslim dominated government forces and the Croat Defence Forces in 1993, a third political unit, the 'Federation of Bosnia and Herzegovina' $(\mathrm{FBiH})$ was created under strong pressure of the American administration through the Washington Agreement of April 1994. Whereas the war constitution of RS provided for a strong central state without any legal reference to ethnic groups, the constitution of $\mathrm{FBiH}$ provided for a bi-national federal state of Muslims, having renamed themselves in 1993 into Bosniacs, and Croats. This federation was also territorially delimited into so-called cantons. Eight of these cantons were populated with either Bosniac or Croat majority population, only two of them were called mixed cantons with no clear-cut majority population. At the federal level, the constitutional provisions introduced an ethno-national power sharing system for the legislative and executive powers, but also for the judiciary. In addition, the Washington Agreement also provided for a Confederation between the newly independent Republic of Croatia and FBiH.

In conclusion, before the end of the war the territorial and institutional make up of political units on the territory of $\mathrm{BiH}$ were characterized by a high degree of territorial and functional asymmetry. In addition, two neighboring states, Croatia and the so-called Federal Republic of Yugoslavia, composed of Serbia 
and Montenegro, both of them under the control of S. Milošević, were parties to the conflict, and there were many efforts of international organizations, in particular the United Nations, and the United States to mediate. However, only after the genocide against 8000 Muslim men and boys committed in Srebrenica in July 1995, they were also ready to intervene militarily in order to stop the war.

Not only had the war caused approximately 100.000 casualities. Almost half of the 4.5 million pre-war inhabitants of $\mathrm{BiH}$ had become refugees all over Europe, Canada, the US and Australia or internally displaced persons (IDPs) by the end of 1995. It can be seen from figures commissioned from the UNHCR and the OSCE by the judge rapporteur for the case No. U-5/98 (see below) of the newly established Constitutional Court of $\mathrm{BiH}$, also the demographic makeup of $\mathrm{BiH}$ had completely changed from a multicultural society with Muslims/ Bosniacs, Croats and Serbs living in all of the municipalities of the former Socialist Republic of $\mathrm{BiH}$ to a strictly ethnically divided society and territorally delimited along ethno-national lines as a consequence of genocide and ethnic cleansing during the war.

A comparison of population figures based on the last census in 1991 with 1997 UNHRC figures reported in the Constitutional Court's case No. U-5/98, Partial Decision III, ${ }^{8}$ demonstrates that the number of Serbs increased from 54.3 to $96.8 \%$ on the territory of RS, whereas the number of Bosniacs dropped from 28.7 to $2.2 \%$ and the number of so-called 'Others' from $7.5 \%$ to zero ( $§ 86$ ). Similar figures demonstrate the effect of ethnic cleansing in $\mathrm{FBiH}$, in particular with the numbers of Serbs decreasing from 17.6 to $2.3 \%$ ( 922 ). What has been overlooked, however, in most scholarly literature concerning the effects of the war, is the degree of ethnic homogenization of the legislative, executive and judicial institutions in those newly established political entities. Again, the figures commissioned for the case No. U-5/98 are self-evident, in particular for the law enforcement bodies: in RS 97.6\% of all judges and prosecutors and $93 \%$ of all police officers were of Serb origin (§ 130). In FBiH there was a strong

Published in Official Gazette of $\mathrm{BiH}, \mathrm{Nr}$. 23/00. All decisions with concurring and dissenting opinions are also published on the webpage of the Constitutional Court of Bosnia-Herzegovina www.ustavnisud.ba., accessed on 18 August 2019. 
preponderance of Bosniac judges and prosecutors with $71.72 \%$ in relation to $23.26 \%$ of Croat origin, whereas only $5.0 \%$ of Serb origin were left in these bodies. The figures for the police forces are similar with slightly more Croats, but only $1.22 \%$ Serbs (§ 136).

In addition, after the end of the war with the General Framework Agreement for Peace in Bosnia and Herzegovina (GFAP), 14 December 1995, ${ }^{9}$ there was with the exception of police forces - no lustration of the entire civil service, the media or the educational system at all territorial levels so that, for instance, pupils could still learn in 2004 from history or geography textbooks in use in RS or the Croat majority cantons of FBiH that 'their' President is either S. Milošević or F. Tudjman with the respective capitals of the, however, neighbouring countries, i.e. Belgrade and Zagreb.

As far as socio-economic conditions are concerned, the entire institutional make up after the Dayton Peace Agreement remained not only strictly ethnically divided, but also created a huge, expensive state machinery with more than 1000 ministers at the level of cantons, entities and the state of $\mathrm{BiH}$ for a population of 3.5 million inhabitants after the war. This huge bureaucratic apparatus is and remains highly ineffective due to the complex allocation of competences and the ethnic divisions so that $\mathrm{BiH}$ remains aid dependent and thus without investment driven and sustainable economic development to this day. As can be seen from long-term trends, there was and still remains also a highly ethnically divided private labor market and official data delivered by the World Bank show an average value in the unemployment rate of $25.06 \%$ between 1991 and 2018 with the highest value of $31.11 \%$ in $2006 .^{10}$ However, as can be seen from reports, youth unemployment is even officially much higher and purportedly one of the highest world wide with approximately more than $60 \%$.

"This climate is linked to the political situation", a figurehead in the Bosnian youth NGO sector argues, "instability, corruption, and complicated bureaucratic

\footnotetext{
9 See the text reprinted in International Legal Materials, 35, no.1 (1996), 75-168.

10 See "Bosnia and Herzegovina/Unemployment rate", The Global Economy, accessed August 18, 2019, https:// www.theglobaleconomy.com/Bosnia-and-Herzegovina/Unemployment_rate.
} 
procedure for development of new businesses or foreign investments." Then the report goes on:

It is this complex maze that youth looking for jobs must navigate; with most of the few employment opportunities secured through political connections and personal networks. As such, many qualified, well educated youth especially those who are loath to give in to the political divisions - are left empty-handed after months of job searching. Most of the private-sector jobs that do exist offer very low wages and poor working conditions. ... The black economy - in which workers do not receive social security, health insurance, or pension payments from their employers - is ubiquitious. So the country now finds itself facing a significant brain drain, with educated, skilled youth deciding that it is easier to look for jobs outside the country ... About 150.000 young people have left since the war ended in 1995, with 10.000 leaving each year. Bosnians living abroad send home remittances that represent 13 percent of the country's GDP, one of the world's highest rate."

Against this political and socio-economic background, we have thus to see what the role of the judiciary, in particular of a constitutional court, can be in terms of social justice in a society in a three-fold transition from war to peace and from a communist regime with a more or less centrally planned economy to a liberal democracy based on a market economy.

\section{THE POLITICAL AND CONSTITUTIONAL SYSTEM}

As the title of the GFAP indicates, this is a framework agreement whose details are spelled out in eleven annexes concerning military matters, the rebuilding of state institutions, reconstruction of the war-torn economy and the return of refugees and IDPs with a strong international involvement for the achievement of these goals. Annex 3 of the GFAP regulates the first free multiparty elections after the war which had to be organized by the OSCE. Annex 6 establishes a Human Rights Commission, to be composed of an international Ombudsperson and a Human Rights Chamber, a body composed of fourteen judges, with a majority of eight judges including the President to be appointed by the Committee of

11 See "Why Bosnia has world's highest youth unemployment rate," Youth Economic Opportunities, accessed August 18, 2019, https://youtheconomicopportunities.org/blog/2971/why-bosnia-has-worlds-highest-youth-unemploymentrate. 
Ministers of the Council of Europe. Annex 7 regulates the rights and duties for the return of refugees and IDPs to their homes of origin and establishes a Real Property Claims Commission to adjudicate on property issues or disputes in this regard. Annex 10 establishes an international High Representative (HR) to oversee and implement the entire civilian aspects of the peace accord and Annex 11 arranges for an International Police Task Force (IPTF), as UNCIVPOL operation under the auspices of the United Nations. Last, but most important for the purposes of this paper, Annex 4 of the GFAP provides for the Constitution of the renamed state "Bosnia and Herzegovina", thereby replacing the previous constitution of the internationally recognized former "Republic of Bosnia and Herzegovina" with its roots in the communist system.

Annex 4, like any other modern constitution therefore regulates the basic legal system of $\mathrm{BiH}$ in terms of institutions and structures. Moreover, it includes a rudimentary human rights catalogue, but in Annex I to Annex 4 alltogether fifteen international human rights instruments were declared directly applicable in $\mathrm{BiH}$, not the least the UN human rights instruments as well as the human and minority rights instruments within the Council of Europe framework. If analyzed both from a constitutional law and political science perspective, it becomes clear that this constitution, having been drafted by US-American lawyers during the negotiations in Dayton/Ohio, was conceived as a political compromise and institutional umbrella for the cease-fire on the ground with many legal lacunae to be filled later by the competent institutions of either the legislative or judicial branches.

A sketch of the institutional structures foreseen in the GFAP in general and Annex 4 in particular will show the following picture:

2. 1. The legal fiction of Article I of the Dayton Constitution, as Annex 4 is colloquially called, declares that "The Republic of Bosnia and Herzegovina ... shall continue its legal existence under international law as a state with its internal structure modified as provided herein...," that is, that RS and FBiH shall form the two "Entities" of Bosnia and Herzegovina 
according to paragraph 3. This means in less diplomatic language: the secessionist and war-faring RS is recognized, not necessarily as a sovereign state in terms of international law, but as a separate, political Entity with its territory occupied by military aggression, ethnic cleansing and genocide in spite of the fact that the UN Security Council had strongly opposed the recognition of new, in my interpretation also internal, borders created by violence. ${ }^{12}$

2. 2. Following the model of the constitution of $\mathrm{FBiH}$ as part of the Washington Agreement, the Dayton Constitution introduces proportional representation and veto powers in the legislative and executive powers for the so called "constituent peoples", that is, Bosniacs, Croats, and Serbs, unlike the FBiH constitution, however, not for "Others." Hence, Article IV provides for a bi-cameral parliament, with a House of Representatives whose members are to be directly elected in a ratio of 2:1 from the territories of FBiH and RS. The House of Peoples is to be composed on the basis of the ethno-national parity principle by five Bosniacs, five Croats, and five Serbs through indirect elections. According to Article V, there shall be a 'collective' Presidency, again to be composed through direct elections on the basis of ethno-national parity with one Bosniac, one Croat, and one Serb member, whereas the provisions for the so called "Council of Ministers" provide for ethno-national representation in a more indirect way. Hence, the only institution at state level with no textual prescription for ethno-national representation is, according to Article VI, the Constitutional Court of $\mathrm{BiH}$ to be composed of nine judges, six of them to be elected by the parliaments of FBiH and RS again in a ratio of 2:1 and three international judges to be selected and appointed by the President of the European Court of Human Rights, established under the European Convention on Human Rights (ECHR). However, as can be seen from this strange rule for the composition of what became called domestic judges in colloquial language, their election

12 See UNSC-Res. 713，25 $5^{\text {th }}$ September 1991. 
by the parliaments of the Entities and not by the parliament at state level, ensures a de facto ethno-national composition to this day with two Serbs from RS, and two Bosniac and two Croats each from FBiH.

2. 3. Again in deviation from the $\mathrm{FBiH}$ constitution, Article IV paragraph 3 and sub-paragraphs d) and e) do not only provide for a so called "vital national interest" veto in the House of Peoples with the effect of a suspensive veto in the legislative process which can be overcome by a mediating mechanism in parliament or, in the final analysis, by a legally binding ruling of the Constitutional Court. Moreover, subparagraph d) enables also a veto mechanism, called "Entity veto", with absolute effect. Hence, practically speaking, nine representatives from RS or eighteen from $\mathrm{FBiH}$ can block any decision-making in the House of Peoples.

2. 4. Finally, what makes $\mathrm{BiH}$ one of the weakest federations worldwide, is the division of powers between the so called common institutions at state level, described above, and the Entity level. Article III of the Dayton Constitution contains a general system of allocation of powers with a list of enumerated powers on behalf of the "institutions of Bosnia and Herzegovina" so that all those powers not contained in the list shall be those of the Entities. From a comparative constitutional law perspective, it is striking that most of the powers which are considered essential for state sovereignty, namely defence, police, or fiscal policy, are not in the list of enumerated powers so that they belong to the Entities. Article VIII even entrenches an almost absolute fiscal dependence of the "common institutions" because they have to be financed from the revenues of the Entitities.

In conclusion, as can be seen from the description above, with the territorial division into two Entities along ethnic lines created by war and ethnic cleansing, the strict corporate ${ }^{13}$ power sharing model entrenched in the constitutions of

${ }_{13}$ Corporate, in contrast to liberal, power sharing is based on the legally entrenched ethno-national predetermination of governmental positions, frequently called 'ethnic keys' in scholarly literature. This distinction can be traced back to Arend Lijphart, "Self-determination versus pre-determination of ethnic minorities in power-sharing systems," reprinted in Will Kymlicka (ed.), The Rights of Minority Culture (Oxford: Oxford University Press, 1995). 
both $\mathrm{FBiH}$ and $\mathrm{BiH}$, and almost no prescriptions for the institutional mechanisms on Entity level or for the coordination and cooperation between Entities and state institutions, the Dayton constitution is based on a political compromise which mirrored the military situation on the ground in terms of a cease-fire arrangement. Moreover, the Dayton constitution like the entire GFAP with its legal nature as a multilateral international treaty entered into force without parliamentary ratification process, nor is the authentic English text officially translated into any of the three official languages in use in $\mathrm{BiH}$.

This must, in line with the title of this paper, trigger the question, why shall and how can such a state and constitution, imposed by international actors and with the bare minimum institutional mechanisms, be kept together? Who and what are possible integrative forces, if it shall not be doomed to become a "defective democracy" at best?14 What are the basic values and (international) constitutional law principles in terms of transitional and social justice, possibly requiring not only political stability through negative peace and co-existence in an ethnically deeply divided society, but also positive peace through cooperation and (re-) integration in terms of reconciliation and social cohesion?15

\section{THE ROLE OF THE CONSTITUTIONAL COURT IN A DIVIDED SOCIETY}

From the perspective which considers legal systems as peaceful dispute resolution mechanisms based on rule of law and not only ethno-national political power sharing because these two principles and their translation into legal and institutional mechanisms might come into conflict, it goes without saying that it is the basic function of a supreme or constitutional court in such a rule of law system that judges should always bear the integration of law, state and society in mind, even if they have to adjudicate, like the Canadian Supreme Court, a claim for secession as this was the case in Reference re Secession of Quebec ([1998] 2

14 On the concept of defective democracies see Wolfgang Merkel, "Embedded and defective democracies," Democratization 11, no. 5 (2004).

${ }^{15}$ See, in particular, Bronwyn Anne Leebaw, "The Irreconcilable Goals of Transitional Justice," Human Rights Quarterly 30, no. 1 (2008). 
SCR 217). As we will see from the case law of the Constitutional Court of $\mathrm{BiH}$, this was even more so the case in $\mathrm{BiH}$ as a state and society still in transition after a protracted violent conflict. Since I have analyzed the implementation of the GFAP in terms of the functioning of the political party system in detail somewhere else, ${ }^{16}$ I will focus in this paper on the comparative constitutional law issues for a constitutional system with a centralized judicial review mechanism. Moreover, I will address the perennial questions of judicial review with regard to the swing of the pendulum between judicial self-restraint and judicial activism in a court with a communist heritage on the one hand, and the permanent equal participation of foreign judges on the other which makes the Bosnian Constitutional Court unique worldwide.

What are, therefore, the underlying notions and premises for such a court when we speak about liberal democracy and market economy, or individual liberal and political human rights in relation with socio-economic and cultural rights? Due to the historic legacy and the involvement of judges coming from different constitutional cultures even in Europe (the foreign judges coming from Sweden, France, and Austria, each from a different 'legal family' with different systems of judicial review) and different ideological viewpoints or legal-theoretical assumptions in terms of positive law, we therefore have a broad range of possible alternatives with regard to questions of social justice, fairness and equality. And what role in particular shall foreigners, sitting with equal rights and duties on the bench of a national constitutional court, play or is this simply a violation of the principle of state sovereignty, as this could be heard as a reproach by politicians and media in $\mathrm{BiH}$, in particular if this is a system imposed on the country?

\subsection{Constitutional Unity or Pluralism: The Contested Institutional Position of the Constitutional Court}

First of all, we have to clarify in howfar Article VI, paragraph 3 of the Dayton constitution foresees a hybrid mix of the US-American and the AustrianGerman systems of judicial review.

$\overline{16}$ See Marko, "Defective Democracy," fn 4. 


\section{1.1. Article VI.3:}

The Constitutional Court shall uphold this Constitution.

a) The Constitutional Court shall have exclusive jurisdiction to decide any dispute that arises under this Constitution between the Entities or between Bosnia and Herzegovina and an Entity or Entities, or between institutions of Bosnia and Herzegovina, including but not limited to:

- Whether an Entity's decision to establish a special parallel relationship with a neighboring state is consistent with this Constitution, including provisions concerning the sovereignty and territorial integrity of Bosnia and Herzegovina.

- Whether any provision of an Entity's constitution or law is consistent with this Constitution.

Disputes may be referred only by a member of the Presidency, by the Chair of the Council of Ministers, by the Chair or Deputy Chair of either chamber of the Parliamentary Assembly, by one-fourth of the members of either chamber of the Parliamentary Assembly, or by one-fourth of either chamber of a legislature of an Entity.

b) The Constitutional Court shall also have appellate jurisdiction over issues under this Constitution arising out of a judgment of any other court in Bosnia and Herzegovina.

c) The Constitutional Court shall have jurisdiction over issues referred by any court in Bosnia and Herzegovina concerning whether a law, on whose validity its decision depends, is compatible with this Constitution, with the European Convention for Human Rights and Fundamental Freedoms and its Protocols, or with the laws of Bosnia and Herzegovina; or concerning the existence of or scope of a general rule of public international law pertinent to the court's decision."

In particular Article VI.3.a) provides a mechanism for what is called in continental European constitutional systems a centralized abstract judicial review procedure. As can be seen from the text, there is no requirement for a dispute between private parties before ordinary civil or criminal law courts, but the Constitutional Court of $\mathrm{BiH}$ functions as a final umpire on disputes between state institutions either on Entity level or between institutions of the Entities and the so-called common institutions on state level. In contrast, Article VI. 3. b) foresees a concrete judicial review procedure with the Constitutional Court as court of final instance, but no power of the 
lower courts to adjudicate on the constitutionality of laws to be applied in the case at hand as can be seen from Article VI. 3. b).

In conclusion, in both abstract and concrete review cases the rulings and judgments of the Constitutional Court with a monopoly to review all sorts of legal acts whether they are in conformity with the constitution, are legally binding not only for the parties, but de facto also serve as a 'precedent' and, if necessary, will abrogate the law in force. Hence, the Bosnian-Herzegovinian system of judicial review resembles more the Austrian-German model of judicial review than the US-system of 'diffuse' judicial review where judges at all levels can set aside legal provisions which they deem inconsistent with the constitution. As I have outlined somewhere else in detail ${ }^{17}$, these comparatively summarising statements above became true, however, only after having established the respective rules by case law of the Constitutional Court itself after disputes with the other institutions, in particular the Human Rights Chamber, the Entity Supreme and Constitutional Courts and, finally, also the High Representative, all of whom had contested the competence of the Constitutional Court of $\mathrm{BiH}$ to rule on appeal against their decisions.

\subsection{The Case-law of the Constitutional Court regarding Socio-economic} Rights

Hence, I will focus on two judgments of the Constitutional Court and the respective reasoning of the majority and dissenting opinions in order to uncover the ideological and legal-theoretical underpinnings concerning the interpretation, in particular methods of interpretation, of liberal human rights, including socio-economic rights in the context of the various spheres of transformation already mentioned above.

\subsubsection{Case No. U-5/98}

Already in 1998, the then Chair of the Presidency, Alija Izetbegović, submitted a request for judicial review with the allegation that more than

${ }_{17}$ See Joseph Marko, "Five Years of Constitutional Jurisprudence in Bosnia and Herzegovina: A First Balance," in European Diversity and Autonomy Papers, 7/2004, accessed 1 September 2019 www.eurac.edu/en/research/ autonomies/minrig/publications/Pages/European-Autonomy-and-Diversity-Papers-(EDAP).aspx. 
twenty provisions of the Entity Constitutions were not in conformity with the Dayton Constitution because the Entity parliaments had violated their obligation from Article XII, paragraph 2 to bring Entity constitutions in line with the Dayton constitution within three months. After more than two years of deliberation, this case, No. U-5/98, was handed down in 2000 in the form of four partial decisions. ${ }^{18}$ Many of the claims made affected the institutional design at Entity level described above so that this request for judicial review was-seen from a political perspective-also an attack on the political compromise concluded in Dayton and constitutionally entrenched with the strict ethno-national power dividing system, in particular the territorial division and, in effect, the ethno-national homogenization of institutions at the Entity level with its effects seen as main obstacles for the reconstruction of the state and the economy. However, in terms of constitution-building and institution-engineering, the architects of Dayton had also insisted on the return of refugees and IDPs, the restitution of property and, in particular, the legal obligation following from Annex VII, Article II: "19. Parties undertake to create in their territories the political, economic, and social conditions conducive to the voluntary return and harmonious reintegration of refugees and displaced persons, without any preference for any particular group."

As one immediately can see from this quote, the provisions of the entire GFAP as a political compromise can have either a static effect, with the ethno-national, power dividing territorial and institutional elements trying to preserve the status quo at the time of the conclusion of the truce, or a dynamic effect to be based on the return of refugees and IDPs if seen as a positive state duty to create the necessary social, economic and political conditions for their reintegration and thus the re-establishment of a multicultural society as it had existed before the war. The entire legal structure

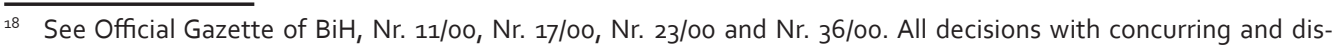
senting opinions are also published on the webpage of the Constitutional Court www.ustavnisud.ba., accessed August 18, 2019. 
and therefore the political compromise in Dayton was obviously based on a constitutional "open-endedness and ambiguity"19 which provided the ground for the judicialization of politics and put the Constitutional Court under enormous political pressure. ${ }^{20}$

It is, therefore, all the more important to reflect on the methods of interpretation in this case and to clarify which different normative force was given to different types of constitutional provisions? There is the rather abstract language of the preambular provisions of Annex 4 referring to the promotion of "the general welfare and economic growth through the protection of private property and the promotion of a market economy" in a situation of transformation from a communist to a democratic system. However, there are the only seemingly much more concrete constitutional rules laid down in the enumeration of liberal human rights in Article II of the Dayton constitution, guaranteeing a "right to property" in general and the "right" of all refugees and IDPs "to freely to return to their homes of origin" and "the right, in accordance with Annex 7 the the General Framework Agreement, to have restored to them the property of which they were deprived in the course of hostilities since 1991 and to be compensated for any such property that cannot be restored to them."

Following from the request of Alija Izetbegović to abrogate Articles 58 and 59 of the RS constitution as violating these constitutional principles and rights, not only the meaning of the normative principle of a market economy, but also the normative substance of the right to property became a matter of strong dispute which was decided by the majority of the Constitutional Court in Partial Decision 2 of case No. U-5/98.

\footnotetext{
19 See Michel Rosenfeld, "Constitutional Identity," in The Oxford Handbook of Comparative Constitutional Law, eds. Michel Rosenfeld and András Sajó (Oxford: Oxford University Press, 2012), 764.

20 See also the reviews of and comments about these judgments by Carsten Stahn, "Die Verfassungsrechtliche Pflicht zur Gleichstellung der drei Ethnischen Volksgruppen in den Bosnischen Teilrepubliken - Neue Hoffnung für das Friedensmodell von Dayton? [The Constitutional Obligation to Guarantee Collective Equality of the Three Ethnic Groups in the Bosnian Entities - New Hope for the Model of Dayton?]" Zeitschrift für öffentliches Recht und Völkerrecht 6o, no. 3-4 (2000); International Crisis Group, "Implementing Equality: The 'Constituent Peoples' Decision in Bosnia and Herzegovina," Balkans Report, No. 128, 16 April 2002; Anna Morawiec Mansfield, "Ethnic but equal: the quest for a new democratic order in Bosnia and Herzegovina," Columbia Law Review 103 (2003).
} 
The contested provisions read as follows:

Article 58, paragraph 1

Property rights and obligations relating to socially-owned resources and the conditions of transforming the resources into other forms of ownership shall be regulated by law.

\section{Article 59}

Natural resources, urban construction sites, real estate and goods of particular economic, cultural and historical significance determined by law to be of general interest, shall be state-owned.

Certain goods of general interest may also be privately owned property under the conditions determined by law.

As one can see from the text, there are the terms and concepts of "sociallyowned", "state-owned" and "privately owned property" and their relationship to be clarified by interpretation. As a precondition, what normative force, if any, does the language of a preambular provision with its reference to economic growth and a market economy have?21 Can the preamble of the Dayton constitution serve as a standard of review for the Entities constitutions? Then what is the normative content of a right to property? Is it - in the classic liberal tradition - only a negative individual human right against state interference and what are then the limits of state interference? Or can it also be more than a negative individual right and create even positive obligations in systematic interpretation with the text of Article II of Annex 7 quoted above?

The majority of the judges followed the opinion written by the judgerapporteur in this case, the author of this paper, by arguing that all constitutional provisions, that is, also the preambular provisions, establish "basic constitutional principles and goals for the functioning of Bosnia and Herzegovina ... that must be perceived as constitutional guidelines or

${ }^{21}$ On the contestation about the normative force of preambles in constitutions see Liav Orgad, "The preamble in constitutional interpretation," $1 \cdot \operatorname{CON} 8$, no.4 (2010). 
limitations for the exercise of the responsibilities of Bosnia and Herzegovina and the Entities." (§ 13). In conclusion, the majority argues under $\S \S 14$ and 15, that there are at least two interpretative doctrines following from the constitutional principles and rights which must serve as a standard for judicial review:

First, the right to private property is not only an individual right, but also an "institutional safeguard" clause:

"Demonstrated by the relationship between 'the protection of privately owned property' and a market economy in the text of the Preamble and Article II of the Constitution of $\mathrm{BiH}$, the right to property is not only an individual right, which requires judicial protection against any illegitimate state interference, but also an institutional safeguard as one of the prerequisites for a functioning market economy."

Second, there is a an absolute limitation against state interference into human rights, originally developed by German constitutional law as so called Wesensgehaltssperre, that is, the absolute limitation to infringe the essence of a human right even through democratic legislation:

It follows from the case law of the European Court of Human Rights that in balancing the demands of the community's general interests, the State's interference with property rights and the requirements of the protection of individual rights, that such a fair balance presupposes the possibility of a balance, i.e. the factual existence of goods in privately owned property. If privately owned property can be reduced to next to nothing through legislation by nationalising, for instance, entire fields of industries, such legislation would fundamentally infringe on the right to property, and in particular, as it is viewed as a necessary requirement of a market economy expressly foreseen by the Constitution of $\mathrm{BiH}$. Therefore, in the final analysis, the supremacy of the Constitution of $\mathrm{BiH}$ in accordance with Article III.3 (b), which supersedes, inter alia, the Constitutions of the Entities, would no longer have any reasonable meaning if it allowed the abolishment of privately owned property. This idea is expressed in the case law of Central European constitutional courts as 'in no case may the essence of a basic right be encroached upon', thereby establishing an absolute restriction on the infringement of constitutionally guaranteed rights through legislation. 
By applying these standards of review, the Court argued under $\S 17$ that the constitutional category of "socially owned" property, which - as a legacy of the former Titoist-communist self-management system - denies both private persons as well as the state the legal status to be considered the owner of property, can no longer be considered to conform to the requirements of the Dayton constitution outlined above, because it creates, in theory and practice, serious obstacles for any privatization process in Bosnia and Herzegovina, in particular for foreign direct investment to create sustainable economic growth and thus "to establish a properly functional market economy."

However, following from judicial self-restraint, the majority of the Court also argued that the challenged provision could be read in two ways, either as a mere legislative authorization of the RS parliament or as a constitutional duty to transform all socially owned property into either private or state owned property in order to promote a mixed economy on the basis of a market system. The majority therefore argued on the basis of a constitutional doctrine to be found in many federal systems that a challenged provision must be upheld as long as it can be interpreted in conformity with the higher ranking law, so that the second alternative has to be applied and therefore it upheld the challenged provision of Article 58, paragraph 1 RS constitution.

In his dissenting opinion, judge Hans Danelius from Sweden and a former judge of the Swedish Supreme Court with, however, no tradition of constitutional judicial review and also a former member of the European Commission of Human Rights, did, based on his experience and the legal doctrines developed by these bodies, deny the first rule elaborated by the majority of the Court concerning a right to property to be seen not only as an individual right, but also as an "institutional safeguard" clause and the conclusion that the contested provision of the RS constitution must be interpreted as a positive duty:

Finally, with respect to the provisions in Article II of the Constitution of $\mathrm{BiH}$, which guarantee the right to property in the context of the general protection of human rights, I find it natural to start the analysis by 
referring to Article 1 of Protocol No. 1 to the European Convention on Human Rights. That Article provides, inter alia, that every natural or legal person is entitled to the peaceful enjoyment of his possessions, that no one shall be deprived of his possessions except on specific enumerated conditions, and that the State shall be free to enforce such laws as it deems necessary to control the use of property in accordance with the general interest.

It appears from the wording of Article 1 of Protocol No. 1 that it is intended to provide protection for the individual's existing property. The provision has generally been understood not to include any right to acquire property, and this interpretation has been confirmed by the European Court of Human Rights, for instance in the case of Marckx v. Belgium (European Court of Human Rights, Judgment of 13 June 1979, Vol. No. 31). Against this background, Article 1 cannot be considered to impose on the State an obligation to privatise State-owned property or otherwise to ensure that certain property is private and not owned by the State or other public organs.

In Article II, paragraph 3 of the Constitution of $\mathrm{BiH}$, the right to property appears as one of numerous enumerated human rights, and there seems to be no reason why the protection of the right to property in this paragraph should be different from the protection provided by Article 1 of Protocol No. 1.

In other words, the right to property as a human right is an individual right. It does not impose obligations regarding the social and economic system of a country. It protects the property which an individual owns at a given moment and does not include any right for him to acquire other property in the future.

Moreover, the majority of the Constitutional Court abrogated the contested provisions of Article 59 RS constitution based on the interpretative doctrine of an absolute limitation for legislation to infringe the essence of human rights:

20 ...To declare natural resources, urban construction sites, and real estate to be state-owned property ex constitutione infringes on the very essence of privately owned property as an individual right and an institutional safeguard.

21. In addition, the ability to expropriate on behalf of the general interests of the State or society was an important element of the communist constitutional doctrine and must thus be viewed as a legacy of that period. If legislation can abolish constitutionally guaranteed rights by 
making reference to unspecified general interests, it would ridicule the basic principle of the rule of law, with the Constitution as paramount, because there is virtually nothing which could not be construed as of 'general' interest. Hence, the Constitutions of the Entities must not grant such broadly construable legislative authorizations that could deprive human rights of any meaning. Such a legal technique violates the principle of efficiency.

\subsubsection{Case No. U-19/o1}

In the end, the second case to be dealt with in our context is Case No. U-19/o1. This was again an abstract review procedure challenging Article 152 of the RS Labour Law, having been adopted in 2000. This case is of special interest with regard to socio-economic rights in the narrower sense, that is, the right to work within the framework of the right of return of refugees and IDPs to their homes, that is, their towns and villages, and be provided with the necessary conditions to make a living in their familiar surroundings. As can be seen from the reasoning of the Constitutional Court in case No. U-5/98 Partial Decision 3, at § 88, one of the contextual elements established to judge discriminatory behaviour against returnees to RS was the discrepancy in numbers between so-called "minority returns", that is, Bosniacs and Croats willing to return to their homes of origin now under the Serb-dominated adminstration of RS, and the overall numbers of returnees insofar only $10.17 \%$ of all returnees did belong to the former category. Moreover, the unemployment rate among returnees was as high as $92 \%{ }^{22}$ Seen against this background Article 152 of the Labour Law of RS stipulated:

Employees having an employment contract on the day of 31 December 1991 with an employer seated on the territory which is now part of Republika Srpska, whose working relationship with that employer was illegally terminated between that date and the effective date of this Law, shall have the right to file a request for severance pay within three months from the effective date of this Law.

22 See Nedim Kulenović, Court as a Policy-Maker?: The Role and Effects of the Constitutional Court of Bosnia and Herzegovina in Democratic Transition and Consolidation (Sarajevo: Working Paper 5/2016, Analitika, Center for Social Research, 2016), 46. 
Moreover, Article 158 established a commission to be appointed by the minister in charge of labor to finally decide on such requests with legally binding effect.

The majority opinion of the Constitutional Court in this case, when reasoning about a possible discriminatory intent of Article 152, made even an abstract reference to Article $6, \S 1$ of ICESCR as legal source to be taken into consideration, but found no evidence for direct or de jure discrimination by the legislator of RS and therefore went on to find out whether the distinction made in the text of Article 152 concerning "persons or groups to be compared" might amount in effect to an indirect or de facto discrimination between Serbs, Bosniacs and Croats due to the historical context of ethnic cleansing when employees were dismissed or put on waiting lists on ethnic grounds. Hence, the majority went on to deliberate on the question whether Article 152 could be considered to have an objective and reasonable justification and established that the overall aim of the contested Article is "creating legal certainty for those companies that ceased or reduced their activities due to the war, and which were after the war faced with the problem of resuming their work under conditions of a market economy. Such legal certainty may also be essential for investors in such companies and for the general development of the economy of Bosnia and Herzegovina" (§ 25). On the other hand, the reasoning goes on,

there is a right of those unlawfully dismissed or placed on a waiting list to be reinstated into their previous positions. Their reinstatement may not be possible in all cases and may largely depend on the economic conditions of their previous employer. Although this individual interest is of high importance, the Constitutional Court considers the public interest outlined above, could reasonably be considered to prevail (\$ 26).

As can be seen from this reasoning, the majority opinion not only ignores to elaborate on the meaning of the right to work, including the right of everyone to the opportunity to gain his/her living by work which he/she freely chooses according to Article $6 \S$ I ICESCR in the context of Bosnia 
and Herzegovina, but also simply applies a mere rationality test in the terminology of the US Supreme Court between a highly abstract public interest, not in any way further empirically substantiated, and the "right" to work, that is, to be reinstated after having been illegally dismissed on ethnic grounds and therefore being seriously discriminated against which is, moreover, linguistically denigrated to a simple "individual interest."

It must therefore come as no surprise that the author of this paper delivered a dissenting opinion in this case and argued that even the majority opinion had recognized that the effects of past de jure discrimination are upheld by Article 152 RS Labor law so that the contested provision must trigger 'strict scrutiny' for review in the terminology of the US Supreme Court, and thus the application of the proportionality principle as the European equivalent in terms of standards of review.

In conclusion, the dissenting opinion outlines that Article 6, § 1 ICESCR has to be read in conjunction with the provisions of Articles II. 5 of the Dayton constitution as a guaranteed right, not simply an individual interest so that the "balancing" of guaranteed rights against public interests requires that all elements of the proportionality test are strictly met. Hence, it has to be tested not only whether the means employed are legitimate and appropriate to achieve the objective, but also whether they are the least restrictive in the guarantee of rights that are available. Seen in this light, Article 152 does not meet the standards of the proportionality test. Its legitimacy must be contested since the recognized illegal dismissals in the past, which formed a part of an organized campaign of ethnic cleansing, are upheld and thereby legalized, creating new discrimination. Second, severance pays instead of reinstatement and the establishment of a commission instead of an independent court in the meaning of Article 6 ECHR to finally decide on requests are not the least restrictive means possible:

16. In times of prosperity, it would certainly be easier to maintain the present workforce while at the same time reinstate former employees. Also, some areas or branches of the labour market may face greater 
difficulties than others. However, it is a constitutional imperative of utmost importance not to uphold discriminatory practices or even create new legislation which discriminates in effect. Thus, the economic burden as a result of the war has to be proportionately distributed between all parts of the population as well as between the private sector and the state budget. An approach which transforms this constitutional obligation into an affirmative action plan to re-employ at least a certain number of Bosniac and Croat men and women would be less burdensome on the victims of discrimination while at the same time taking into account the present economic difficulties. Most importantly, it would give returnees the same chance to access the limited available positions as the majority Serb population presently have, and thereby bring the right to return into balance with the public interest in a sustainable economy. Lastly, such legal guidelines on a proportionate distribution of the existing positions according to criteria of professional qualification would meet the obligation of the public authorities to facilitate the return process.

Hence, the conclusion of the dissenting opinion:

17. In view of feasible alternatives which the majority Decision does not take into consideration, Article 152 of Labour Law of the RS, by categorically excluding any reinstatement nor providing for any equivalent solution, cannot be considered a necessary and proportionate means. Article 152 of Labour Law of the RS does not find a reasonable relationship of proportionality between the means employed (symbolic compensation and exclusion of any reinstatement) and the aim sought to be realised (compensation for suffered discrimination under tight economic conditions). It is thus discriminatory and in violation of Article II.4 in conjunction with Article II.5 of Constitution and Article $6 \S 1$ ICESCR, Annex I of Constitution of Bosnia and Herzegovina.

\section{CONCLUSIONS}

As can be seen not only from these judgments, ${ }^{23}$ most of the problems of the reconstruction of the state and economy and reconciliation of society in terms of the civilian implementation of the GFAP were brought before the Constitutional Court of $\mathrm{BiH}$. Seen from hindsight, the Constitutional Court of $\mathrm{BiH}$ was, through the judicialization of politics in a process of triple transformation after a terrible war, necessarily a very active court and thus, together with the High

\footnotetext{
${ }_{23}$ See in particular the more than 1000 pages commentary by Nedim Ademović and Christian Steiner, Constitution of Bosnia and Herzegovina. Commentary (Sarajevo, Konrad-Adenauer-Stiftung, 2010).
} 
Representatives in $\mathrm{BiH}$, probably one of the two institutions constantly working for the reintegration of state and society inspite of the de facto ethno-national composition among 'domestic' judges and the participation of three international judges. Concerning the role of the latter in processes of constitutional adjudication, two phenomena must be highlighted. In terms of human rights protection, their role was to serve as translators and mediators for the domestic judges, because all of them had been trained under the communist system and therefore had no experience with the ECHR and its implementation in the member states of the Council of Europe or the case law of the European Court of Human Rights. In this regard, all the judges irrespective of their ethnic feelings developed an esprit de corps concerning the protection of liberal, that is, negative human rights against infringements by public authorities.

Secondly, and astonishingly, as could be seen from the description and analysis of the two cases above, most conflicts of interpretation in terms of ideological underpinnings and legal-theoretical assumptions concerning the relationship between liberal, negative rights and social rights and corresponding positive duties of state authorities did not flare up between domestic judges trained under the communist regime and international judges coming from liberal-democratic regimes, but among the international judges themselves coming from different legal cultures with different practices of judicial review. However, as can be seen from the overview on the case law of the Constitutional Court of $\mathrm{BiH}$ analysed by Ademović and Steiner, quoted above in footnote 17, questions and problems of socio-economic rights in the narrow meaning did not play a prominent role in the adjudication of the Constitutional Court of $\mathrm{BiH}$, and if, only in connection with problems of discrimination on the basis of ethnic origin.

\section{BIBLIOGRAPHY}

Abazović, Mirsad. Nacionalni Aspekti Kadrova u BiH 1945-1991 [National Aspects of the Formation of Cadres in Bosnia and Herzegovina 1945-1991]. Sarajevo: Bibliotheka Posebna Izdanja, br. 66, 2000. 
Ademović, Nedim and Christian Steiner. Constitution of Bosnia and Herzegovina. Commentary. Sarajevo: Konrad-Adenauer-Stiftung, 2010.

Bowring, Bill. The Degradation of the International Legal Order? The Rehabilitation of Law and the Possibility of Politics. New York: Routledge and Cavendish, 2008.

Constitutional Court of Bosnia and Herzegovina, Case No. U-5/98.

Constitutional Court of Bosnia and Herzegovina, Case No. U-19/o1.

General Framework Agreement for Peace, in International Legal Materials 35, No.1 (1996), 75-168.

International Crisis Group, "Implementing Equality: The Constituent Peoples Decision in Bosnia and Herzegovina," Balkans Report, no. 128, 16 April 2002. Kulenović, Nedim. Court as a Policy-Maker?: The Role and Effects of the Constitutional Court of Bosnia and Herzegovina in Democratic Transition and Consolidation, Working Paper 5/2016. Sarajevo: Analitika, Center for Social Research, 2016.

Leebaw, Bronwyn Anne. The Irreconcilable Goals of Transitional Justice. Human Rights Quarterly 30, no. 1 (2008): 95-118.

Lijphart, Arend. "Self-Determination versus Pre-Determination of Ethnic Minorities in Power-Sharing Systems." In The Rights of Minority Culture, edited by Will Kymlicka, 275-87, Oxford: Oxford University Press, 1995.

Marko, Joseph. "Autonomy or Partition? The Ethno-National Effects of Territorial Delimitation in Bosnia and Herzegovina." In Local-Self-Government, Territorial Integrity and Protection of Minorities, edited by the Swiss Institute of Comparative Law, Publications of the Swiss Institute of Comparative Law, 121-143, Zurich: Schulthess, 1996.

Marko, Joseph. "Five Years of Constitutional Jurisprudence in Bosnia and Herzegovina: A First Balance." European Diversity and Autonomy Papers 7/2004, 2004 at www.eurac.edu/en/research/autonomies/minrig/publications/ 
Pages/European-Autonomy-and-Diversity-Papers-(EDAP).aspx, accessed September 1, 2019.

Marko, Joseph. "Defective Democracy in a Failed State? Bridging Constitutional Design, Politics and Ethnic Division in Bosnia-Herzegovina." In Practising Self-Government: A Comparative Study of Autonomous Regions, edited by Yash Gai and Sophia Woodman, 281-314. Cambridge: Cambridge University Press, 2013.

Marko, Joseph. "Ethnopolitics and Constitutional Reform in Bosnia and Herzegovina." In Bosnia-Herzegovina since Dayton: Civic and Uncivic Values, edited by Ola Listhaug and Sabrina P. Ramet, 49-80. Ravenna: Longo Editore, 2013.

Merkel, Wolfgang. "Embedded and Defective Democracies." Democratization 11, no. 5 (2004).

Morawiec Mansfield, Anna, "Ethnic but Equal: the Quest for a New Democratic Order in Bosnia and Herzegovina." Columbia Law Review 113, (2003).

Orgad, Liav. "The Preamble in Constitutional Interpretation." I•CON 8, no.4, (2010).

Ramet, Sabrina P. The Three Yugoslavias: State-Building and Legitimitation, 1919-1992. Washington: Indiana University Press, 2006.

Rosenfeld, Michel. "Constitutional Identity." In The Oxford Handbook of Comparative Constitutional Law, edited by Michel Rosenfeld and András Sajó (Oxford: Oxford University Press, 2012).

Stahn, Carsten. "Die Verfassungsrechtliche Pflicht zur Gleichstellung der drei Ethnischen Volksgruppen in den Bosnischen Teilrepubliken - Neue Hoffnung für das Friedensmodell von Dayton? [The Constitutional Obligation to Guarantee Collective Equality of the Three Ethnic Groups in The Bosnian Entities - New Hope for The Model of Dayton?]." Zeitschrift für öffentliches Recht und Völkerrecht 6o, no. 3-4 (2000). 
The Global Economy. "Bosnia and Herzegovina/Unemployment Rate." Accessed August 18, 2019. https://www.theglobaleconomy.com/Bosnia-andHerzegovina/Unemployment_rate.

UNSC-Resolution 713, 25 $5^{\text {th }}$ September 1991.

Youth Economic Opportunities. "Why Bosnia has the World's Highest Youth Unemployment Rate.” Accessed August 18, 2019. https:// youtheconomicopportunities.org/blog/2971/why-bosnia-has-worlds-highestyouth-unemployment-rate. 